\title{
RIFTING AND MAGMATISM ASSOCIATED WITH THE SOUTH AMERICA AND AFRICA BREAK UP
}

\section{ANTONIO THOMAZ FILHO ${ }^{1}$, ANA MARIA PIMENTEL MIZUSAKI ${ }^{2}$, EDISON JOSE MILANI ${ }^{3}$ AND PEDRO DE CESERO ${ }^{1}$}

\begin{abstract}
Based on about $380 \mathrm{~K} / \mathrm{Ar}$ dating of basic and alkaline magmatic rocks from Brazilian sedimentary basins and the Argentinean Atlantic margin it is possible to interpret the evolution of the rifting that caused the South America and Africa break-up. This process started in the Triassic and took place northwestward of the Foz do Amazonas Basin, on the equatorial Brazilian continental margin, and reached the San Julian and North Malvinas basins, in the southern portion of South America. From this latter region up to the Espírito Santo Basin, rifting took place between the Jurassic and Neocomian whereas transcurrence caused by clockwise rotation of South America on the equatorial margin generated the Potiguar Basin. The available information suggests that the final break-up of Africa and South America occurred along the eastern Brazilian margin, between the Cumuruxatiba/Mucuri and Pernambuco basins, during the Cenomanian/Turonian.

The resistance offered by the São Luis/West African and São Francisco/Congo cratons promoted the huge magmatic manifestations which occur in the Brazilian Paleozoic intracratonic basins (Acre, Solimões, Amazonas, Parnaíba and Paraná basins) as well as in the interior Tacutu Rift. Hot spots turned out during the drift phase, as registered by the Mecejana (CE)/Rocas Atoll/Fernando de Noronha Archipelago Alignment and Poços de Caldas/Cabo Frio Alkaline Rocks Alignment that persists up to the Vitória/Trindade Chain.
\end{abstract}

Keywords:

INTRODUCTION The commonly basic, intrusive and extrusive magmatic rocks related to continental rifting tend to be reliable chronometers for radiometric dating by the K/Ar method due to their relatively fast crystallization on the crust surface. Therefore, unless hydrothermal, diagenetic or weathering alterations have taken place, $\mathrm{K} / \mathrm{Ar}$ dating of these rocks can be considered excellent geological markers of the initial tectonic processes related to the continental break-up.

These processes, which culminate in the ocean formation, as in the case of South American and African rupture, have as their starting point the formation and evolution of active rifts, following Condie's (1997) conception. These rifts are produced by the uplift and break of the lithosphere due to crustal expansion due to heating caused by the elevation of the asthenosphere or mantelic plumes that, by adiabatic decompression, experience partial melting and generated basaltic magmatism. Consequently, active rifts normally comprise significant volumes of basic volcanic rocks whose presence decreases during the rift evolution.

This paper, based on about $380 \mathrm{~K} /$ Ar dating (Mizusaki et al. 1998) of basic and alkaline magmatic rocks from the Brazilian and Argentinean Atlantic margin basins, is an attempt to interpret, in terms of space and time, the geotectonic framework in which rifting has evolved and caused the break-up of South America and Africa, hence forming the South Atlantic Ocean.

\section{THE DISTRIBUTION OF THE MAGMATISM ASSOCIATED} WITH THE BREAK-UP OF SOUTH AMERICA AND AFRICA Figure 1 shows the distribution of $377 \mathrm{~K} / \mathrm{Ar}$ radiometric dating of basic and alkaline magmatic rocks presented by Mizusaki et al. (1998) and related to the rifting that produced the break-up between South America and Africa. Major incidences of basic magmatic activity are remarkable around $210 \mathrm{Ma}$ (Triassic), $180 \mathrm{Ma}$ (Neocomian) and 90 $\mathrm{Ma}$ (Santonian/Turonian) and basic/alkaline magmatic manifestations around $50 \mathrm{Ma}$ (Eocene) and $10 \mathrm{Ma}$ (Oligocene). This pattern of age distribution in the Brazilian sedimentary basins, added to the ages obtained on the Argentinean Atlantic margin (Rapela \& Pankhurst 1994, Baldi \& Nevistic 1996, Linares 1977, Lesta et al. 1980, Stoakes et al. 1991), is shown in figure 2. Large episodes of intrusive and extrusive magmatism are represented in the Paleozoic intracratonic basins (Acre, Solimões, Amazonas, Parnaíba and Paraná basins). In the Brazilian and Argentinean marginal basins magmatic rocks occur in the rift sequences and are normally interlayered with immature clastic sedimentary rocks.

\section{THE CHRONOLOGY OF SOUTH AMERICAN AND} AFRICAN DRIFT Figure 2 shows that the precursor rifting associated with South America and Africa break-up began in the Triassic on the Brazilian equatorial margin, and took place from NW (French Guyana) to SE (Foz do Amazonas/Marajó Basin). Further to SE, rifting evolution has probably been hindered by the strong resistance offered by the São Luis/West African Craton, causing large magmatic manifestations in the Acre, Solimões, Amazonas and

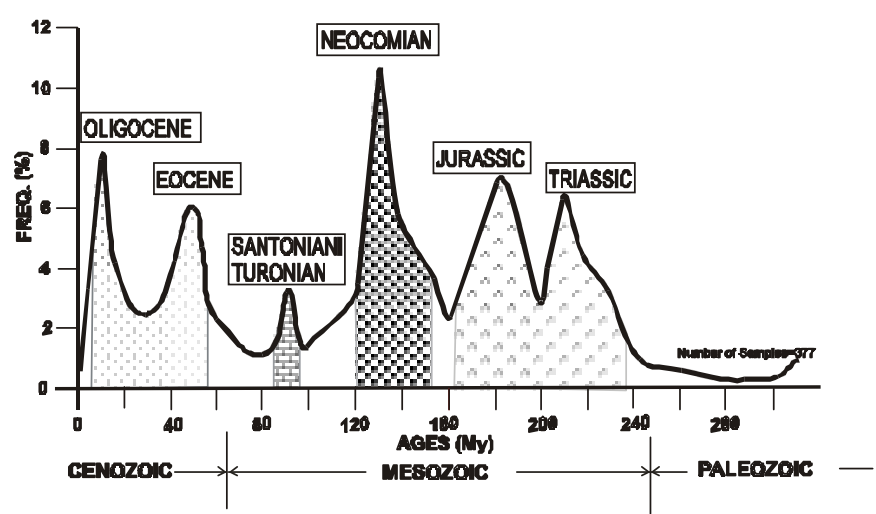

Figure 1 - K/Ar dating of the basic and alkaline magmatism and relation with the geologic time.

Parnaíba Paleozoic intracratonic basins and in the Tacutu interior rift. This magmatic extrusion is supposed to have attenuated the energy related the rifting tectonic process southeastward of the Foz do Amazonas/Marajó Basin.

At the same time, still during the Triassic, the rifting of the southern portion of South America also took place, as deduced by the presence of the $200 \mathrm{Ma}$ old dykes of basic magmatic rocks (Uliana \& Biddle 1988 ) and by the significant, rift-related manifestations of Triassic magmatic rocks in the marginal San Julian and North Malvinas basins (Rapela \& Pankhurst 1994).

During the Jurassic, rifting evolved northwards on the Argentinean coast and reached the San Jorge and Valdez/Rawson marginal basins. At the same time, intense magmatism in the Acre, Solimões, Amazonas and Parnaíba Paleozoic interior basins was still active.

In the Neocomian, in the southern portion of South America, rifting evolved along Argentina's Colorado and Salado and Brazil's Pelotas, Santos, Campos and Espírito Santo marginal basins. At the same time, and similar to that of the equatorial margin, the resistance offered by the São Francisco/Congo Craton probably attenuated rifting evolution and propitiated the large volcanic manifestations represented by the Serra Geral (Paraná Basin) and Kaoko (Namibia) basalt (Siedner \& Michell 1976). This resistance has also caused the development of the Curitiba/Maringá Fault Zone, in Brazil, and the evolution of the Salado and Colorado rift, in Argentina (Conceição et al. 1988). At the same time, due to the clockwise rotation of South America (Szatmari et al. 1987), transcurrence was taking place on the equatorial margin. This caused compression and distension northwestwards and southeastwards, respectively, to the present day location of the city of Fortaleza, and transtension formed the Potiguar basin and E-W trending diabase dykes intrusions.

The scarcity of magmatic manifestation along the eastern Brazilian coast, between the Cumuruxatiba and Pernambuco/Paraíba basins, constitutes a remarkable feature related to the South America/Africa

3 - PETROBRAS, Av. Chile 65-1301B, 20035-900-Rio de Janeiro (RJ) 


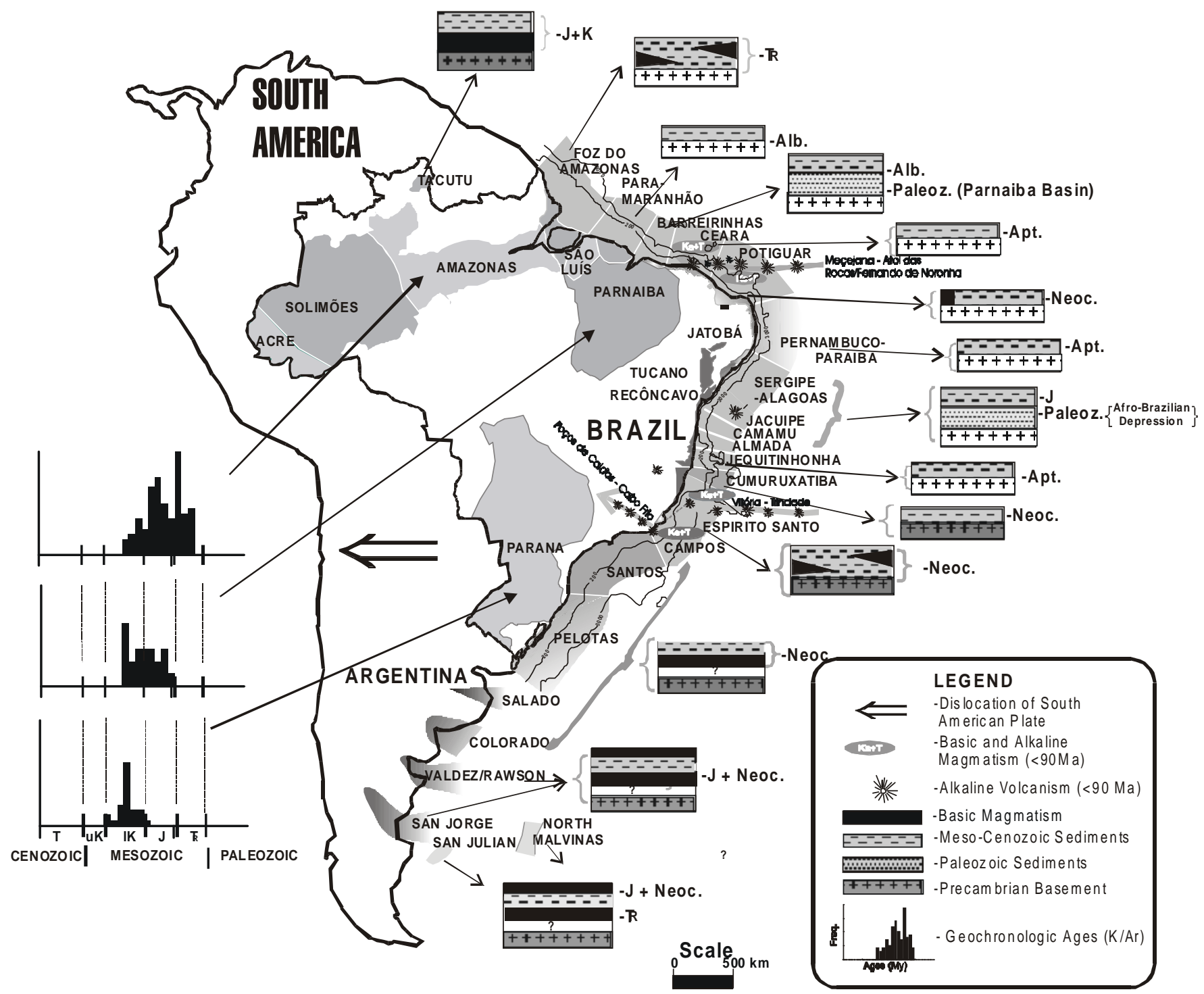

Figure 2 - K/Ar dating of the basic magmatism associated with the rift phase in the marginal basins of South America, the basic magmatism of intracratonic basins and the basic and alkaline magmatism associated with South America and Africa break-up.

break-up. In this segment, deep rifts in which the magmatic activity was restricted to their distal portions, as shown in some seismic lines $(<$ biblio $>$ ) characterize the marginal basins. Geochronological, micropaleontological, sedimentological and geochemical data suggest that the final separation of South America and Africa occurred along the eastern Brazilian margin, between the Cumuruxatiba/Mucuri and Pernambuco basins, during the Cenomanian/Turonian (Schlanger et al. 1981, Dias Brito 1987, Chang \& Kowsmann 1987, Koutsoukos et al. 1991 A, B, Koutsoukos 1992, Koutsoukos \& Bengston 1993, and Pereira 1992, 1994). Therefore, the magmatic rocks present in the deepest portions of the marginal basins of the eastern Brazilian coast can be related to the final separation of South America and Africa and are likely to be around 90 Ma old.

From the upper Cretaceous to the Tertiary, during the drift phase of the South Atlantic Ocean evolution, the volcanic manifestations presented an alkaline character and a linear trend of successive events that suggest hot spot activity. Mizusaki et al. (1999, in press) suggested that the Mecejana (near Fortaleza City - CE)/Rocas Atoll/Fernando de Noronha Archipelago Volcanic Alignment was caused by hot spot activity. Similarly, Thomaz-Filho \& Rodrigues (1999) concluded that the Poços de Caldas/Cabo Frio Alkaline Rocks Alignment would be linked to the Vitoria-Trindade Chain (located in the oceanic area) and represent, as a whole, the product of one hot spot.
CONCLUSIONS Figure 3 shows a sketch supposed to represent the temporal evolution of the process of break-up and drift of the South American and African continents (Mizusaki et al. 1998).

From 230 to $170 \mathrm{Ma}$, with two phases of more expressive incidence of magmatism in the Triassic and Jurassic, rifting evolved on the equatorial margin from the French Guyana to the Foz do Amazonas/Marajó Basin. At the same time, rifting took place in the southern portion of South America, at least reaching the San Julian and North Malvinas basins, on the Argentinean coast. From 170 to $120 \mathrm{Ma}$, with a peak of incidence during the Neocomian, rifting proceeded along the Argentinean, Uruguayan and Brazilian coast up to the Espírito Santo Basin. At the same time, a clockwise rotation of South America promoted dextral transcurrent displacements on the equatorial Brazilian margin and the Potiguar Basin Formation. Around $90 \mathrm{Ma}$, the final detachment of the South American and African continents took place along the eastern Brazilian coast. From this time up to the Recent, with peaks of magmatic activity in the Eocene and Oligocene (Fig. 1), a continuous separation of the South American and African continents has occurred and favored magmatic activity, in some cases ascribed to the action of hot spots. The large magmatic manifestation present in the Brazilian interior sedimentary basins was probably caused by the resistance to break offered by the São Luis/West African Craton, on the equatorial margin, and by the São Francisco/Congo Craton, on the eastern Brazilian margin. 

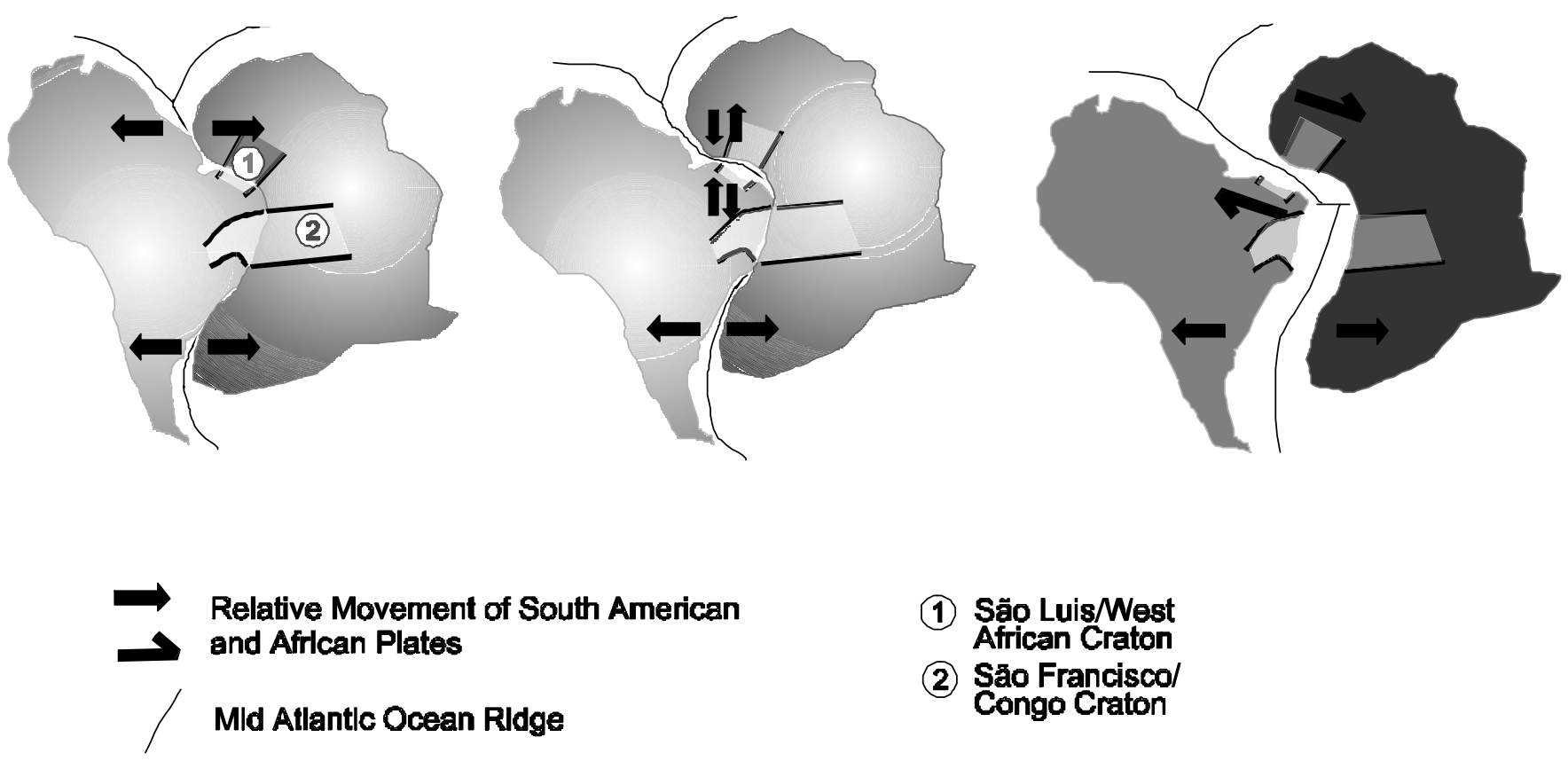

(1) Säo Luis/West African Craton

(2) São Franciscol Congo Craton

Figure 3 - General sketch of South America and Africa break-up proposed according to the evolution along the geologic time (modified from Mizusaki et al. 1988).

\section{References}

Baldi J.E. \& Nevistic V. A 1996. Cuenca costa afuera del Golfo San Jorge. In: Ramos V.A \& Turic M.A (eds.), Geologia y Recursos naturales de la plataforma continental Argentina. Association Geológica Argentina/Instituto Argentino del Petróleo, Buenos Aires, Argentina, 171-192.

Chang H. K. \& Kowsmann R. 1987. Interpretação genética das sequências estratigráficas das bacias da margem continental brasileira. Revista Brasileira de Geociências, 17:74-80.

Conceição J.C.J., Zalán P.V., Wolff S. 1988. Mecanismo de evolução e cronologia do rifte sul-atlântico. Boletim de Geociências da Petrobras, 2:255-265.

Condie K.C. 1997. Plate tectonics and crustal evolution. Butterworth-Heinemann, Linacre House, Jordan Hill, Oxford, $282 \mathrm{p}$

Da Silva H.T.F. \& Mendes J.M.C. 1998. Exploratory overview of a mature basin: the Sergipe-Alagoas Basin, northeastern Brazil. In: Oil and Gas International Conference \& Exhibition, 1998, Rio de Janeiro. Extended Abstracts, I:482-483.

Dias-Brito D. 1987. A Bacia de Campos no Mesocretáceo: uma contribuição à paleoceanografia do Atlântico Sul primitivo. Revista Brasileira de Geociências, 17:162-167.

Koutsoukos E.A.M., Mello M.R., Azambuja Filho N.C. 1991. A micropalaeontological and geochemical evidence of Mid-Cretaceous dysoxic-anoxic palaeoenvironments in the geochemical evidence of Mid-Cretaceous dysoxic-anoxic
Sergipe Basin, Brazil. Special Publication, 58:427-447.

Koutsoukos E.A.M., Mello M.R., Azambuja Filho N.C., Hart M.B., Maxwell J.R. 1991 The upper Aptian-Albian sucession of the Sergipe Basin, Brazil: an integrated palaeoenvironment assessment. Bulletin of American Association of Petroleum Geology, 75:479-498.

Koutsoukos E.A.M. \& Bengston P. 1993. Towards an integrated biostratigraphy of the upper Aptian-Maastrichtian of the Sergipe Basin, Brazil. Document Laboratoire Geólogique Lyon, 125:241-262.

Lesta P., Mainard E., Stubelj R. 1980. Plataforma continental Argentina. In: Turner J.C.M. (ed.) Proceedings of the Segundo Simposio de Geologia Regional Argentina. Acad. Nacional de Ciências, Argentina, 1577-1601.

Linares E. 1997. Catalogo de edades radiométricas determinadas para la Republica Argentina. Associatión Geológica Argentina, publication especial B-4, Buenos Aires, Argentina.

Mizusaki A. M. P., Thomaz-Filho A., Cesero P. de 1998. Ages of the magmatism and the opening of the South Atlantic Ocean. Pesquisas, 25:45-57.
Mizusaki A.M.P., Thomaz-Filho A., Milani E.J., Cesero P. de 1999. Mesozoic and Cenozoic igneous activity and its tectonic control in the northeastern region of Brazil, South America . Marine and Petroleum Geology (submitted).

Pereira M.J. 1992 . Consideraç̃es sobre a estratigrafia do Cenomaniano-Santoniano em algumas bacias marginais brasileiras e sua implicação na história tectônica e sedimentar da margem continental. Boletim de Geociências da Petrobrás, 6(3/ 4):171-176.

Pereira M.J. 1994. Sequências deposicionais de $2^{\mathrm{a}}$ e $3^{\mathrm{a}}$ ordens (50 a 2,0 Ma) e tectonoestratigrafia no Cretáceo de cinco bacias marginais do Brasil: comparação com outras áreas do globo e implicações geodinâmicas. In: Simpósio sobre o Cretáceo do Brasil, Anais, 1-12.

Rapela C.W. \& Pankhurst R. 1994. Variaciones temporales y composicionales del magmatismo jurásico

de la Patagonia. In: VIII Congresso Geológico Chileno II, Proccedings, 1433-1437.

Schlanger S.O., Jenkins H.C., Premoti-silva I. 1981. Volcanism and vertical tectonics in the Pacific Basin related to global Cretaceous transgressions. Earth Planetary Science Letters, 52:4435-449.

Siedner G. \& Mitchell J.G. 1976. Episodic mesozoic volcanism in Namibia and Brazil: KAr isochron study bearing on the opening of the South Atlantic. Earth Planetary Science Letters, 30:292-302.

Stoakes F.A., Campbell C.V., Cass R, Ucha N. 1991. Seismic stratigraphic analysis of the Punta del este Basin, offshore Uruguay. American Association of Petroleum Geologists Bulletin, 75(2):219-240.

Szatmari P., Françolin J.B.L., Zanotto O., Wolff S. 19987. Evolução tectônica da margem equatorial brasileira. Revista Brasileira de Geociências, 17:180-188.

Thomaz-Filho A. \& Rodrigues A L. 1999. O alinhamento de rochas alcalinas Poços de Caldas-Cabo Frio (RJ) e sua continuidade na cadeia Vitória-Trindade. Revista Brasileira de Geociências, 29(3) (no prelo).

Uliana M.A. \& Biddle K.T. 1988. Mesozoic-Cenozoic paleogeographic and geodynamic evolution of southern South America. Revista Brasileira de Geociências, 18:172190 .

Contribution IGC-020

Received January 20, 2000 Accepted for publication April 26, 2000 